Jurnal Konstruksi Hukum | ISSN: 2746-5055

Vol. 2, No. 2, Mei 2021, Hal. 303-308| Tersedia online di

https://www.ejournal.warmadewa.ac.id/index.php/jukonhum

DOI: https://doi.org/10.22225/jkh.2.2.3227.303-308

\title{
KEDUDUKAN SUAMI MENURUT HUKUM WARIS BALI DALAM PERKAWINAN NYEBURIN DI DESA ADAT PELIATAN UBUD GIANYAR
}

\author{
Cokorda Gde Yudha Putra, I Made Suwitra, Gayatri Sudibya Diah \\ Fakultas Ilmu Hukum Universitas Warmadewa \\ cokdeyuda69@gmail.com, madesuwitra27@gmail.com, diahgayatrisudibya@gmail.com
}

\begin{abstract}
Abstrak
Laki-laki Bali adalah pelanjut garis keturunan/pelanjut masa depan keluarga sehingga sebuah keluarga tetap mempunyai pelanjut keturunan dan tidak mengalami kepunahan. Namun harapan-harapan tersebut tidak bias menjadi kenyataan apabila pasangan suami istri tersebut tidak bias melahirkan anak lak-laki atau bahkan tak memiliki anak atau keturunan sama sekali. Tujuan penelitian ini adalah untuk mengetahui hukum waris bali dalam perkawinan nyeburin di desa adat Peliatan. Adapun rumusan masalah dalam penelitian ini yaitu bagaimanakah kedudukan suami dalam kawin Nyeburin menurut Awig-Awig Desa Adat Peliatan dan faktor yang mendorong pelaksanaan perkawinan Nyeburin di Desa Adat Peliatan. Tipe penelitian yang dipergunakan adalah empiris dengan menggunakan pendekatan sosiologis, pendekatan perundang-undangan, konseptual, kasus dan pendekatan hukum adat. Adapun sumber data yang diperoleh dari penelitian ini adalah data primer yang bersumber dari wawancara dan observasi serta data sekunder yang berasal dari Awig-awig desa adat, perundang-undangan dan penelitian terkait. Hasil penelitian antara lain kedudukan suami selaku predana dalam kawin nyeburin menurut Awig-Awig Desa Adat Peliatan, bila putusnya perkawinan baik yang masih tinggal di rumah istrinya ataupun yang telah pulang ke rumah asalnya (mulih deha/truna), belum ada yang mengatur secara tegas dalam aturan hukum positif. Faktor yang mendorong pelaksanaan perkawinan Nyeburin di Desa Adat Peliatan yaitu karena permintaan orang tua si wanita akibat tidak mempunyai anak laki-laki dan hanya mempunyai anak perempuan saja, faktor yang dating dari pihak laki-laki (sebagai predana) yaitu karena adanya saling mencintai diantara kedua belah pihak.
\end{abstract}

Kata Kunci: Hukum Waris Bali, Kedudukan Suami dan Perkawinan Nyeburin

\begin{abstract}
Balinese men are the successors of the lineage / continuation of the future of the family so that a family continues to have descendants and does not experience extinction. However, these hopes cannot come true if the married couple cannot give birth to a son or even have no children or offspring at all. The purpose of this study was to determine the law of Balinese inheritance in nyeburin marriages in the traditional village of Peliatan. The formulation of the problem in this study is what is the position of the husband in the Nyeburin marriage according to the Awig-Awig of the Peliatan Traditional Village and the factors that encourage the implementation of the Nyeburin marriage in the Peliatan Traditional Village. The type of research used is empirical using a sociological approach, statutory approach, conceptual, case and customary law approaches. The data sources obtained from this research are primary data from interviews and observations and secondary data from Awig-awig traditional villages, legislation and related research. The results of the research include the husband's position as predana in intermarriage according to the Awig-Awig of the Peliatan Traditional Village, if the marriage breaks either those who still live at their wife's house or who have returned to their original home (mulih deha / truna), no one has explicitly regulated in positive rule of law. The factors that encourage the implementation of the Nyeburin marriage in the Peliatan Traditional Village are due to the request of the woman's parents due to not having a son and only having a daughter, a factor that comes from the male side (as predana), namely because of mutual love between the two both sides.
\end{abstract}

Keywords: Husband's Position, Bali Inheritance Law, and Merry Marriage

\section{PENDAHULUAN}

Berdasarkan saat ini, sistem kekerabatan yang paling dominan ada di tengah-tengah masyarakat Bali adalah sistem kekerabatan yang disebut dengan sistem Patrilinial sedangkan patri loka merupakan sebutan untuk adat ketika menetap atau tinggal setelah melakukan pemikahan. Dalam istilah Bali, sistem ini mengikuti garis keturunan laki-laki atau disebut dengan istilah Purusa dalam sistem kekerabatan ini. (Koentjaraningrat, 2000: 261). Dilihat dari bagaimana anak laki-laki yang memiliki 
peran dominan dalam suatu keluarga, yang mana menjadikannya sebagai ahli waris mutlak dalam silsilah keluarganya. Sehingga segala bentuk hak serta kewajiban baik berwujud berupa harta warisan hingga beban tanggung jawab lebih ditanggungkan kepadanya daripada kepada anak perempuan maka dari itu, sebagaimana kepercayaan di Bali, kewajiban serta hak yang dulunya milik orang tua beralih kepada anak laki-laki mereka baik itu hak atau kewajiban kepada Tuhan, sesama maupun lingkungannya. lni juga dapat dilihat dengan mana laki-laki berkedudukan lebih yaitu sebagai Purusa dalam suatu perkawinan Hindu di Bali. Istri kehilangan hak serta tanggung jawab dari keluarganya, dan sekarang menjadi tanggung jawab dari suami yang meminangnya. Itulah kemampuan laki-laki yang mampu menarik perempuan untuk dijadikan istri, serta menjaminnya setelah lepas dari keluarga atau orang tua mereka. Dari beberapa paparan tersebut, itu merupakan konsekuensi dan merupakan adat serta budaya yang timbul akibat dari sistem patrilinial yang dianut masyarakat hukum adat di Bali.

Tujuan perkawinan bagi masyarakat hukum adat yang bersifat kekerabatan adalah untuk mempertahankan dan meneruskan keturunan menurut garis ke-bapaan atau ke-ibuan atau ke-ibubapaan (Anggraini \& Gunawijaya, 2018). Tujuan perkawinan menurut hukum agama Hindu adalah untuk mendapatkan keturunan dan untuk menebus dosa-dosa orang tua dengan menurunkan seorang putra (Pudja, 1974). Dalam perkawinan, tujuannya adalah menghasilkan keturunan kelak dan itu yang juga merupakan peran dari seorang laki-laki, khususnya dalam hal ini laki-laki Bali yang dalam sistem patrilinial ini berperan untuk melanjutkan keturunan keluarga. Akan tetapi, dalam hal ini tak berlaku jika suatu keluarga tak memiliki anak laki-laki, lalu bagaimana konsekuensinya. Hal ini masih menjadi perdebatan, mengingat dalam hukum positif, tak ada bedanya antara laki-laki dan perempuan, dan itu bukanlah masalah, namun kita tetap juga tak bisa mengabaikan hukum adat yang telah berlangsung lama yang telah dipercaya masyarakat selama ini.

Didasari pada Budaya serta agama yang ada itulah mengapa sistem kekerabatan patrilineal ini memiliki kesakralan serta nilai adatnya begitu kental maka tak heran hal itu sejalan dengan norma yang tumbuh hidup serta berkembang dalam masyarakat, tak ayal eksistensinya masih diakui dan dianut oleh masyarakat setempat. Dalam norma berupa hukum adat yang ada dan berbeda di tiap daerah di bali, yang mana pengaturannya begitu relevan dengan kehidupan masyarakat, sehingga dapat menjadi solusi dari berbagai permasalahan masyarakat. Oleh karenanya, anak laki-laki merupakan penerus keturunan selanjutnya bagi suatu keluarga, sedangkan perempuan di Bali hanyalah berhak menikmati harta waris atau peninggalan dari orangtuanya selama ia belum kawin (Sutardjana, 2006).

Dalam Hindu di Bali, ada dimana ketika laki-laki dianggap sebagai wanita dan dipinang layaknya wanita oleh calon mempelai wanitanya itu disebutperkawinan nyeburin, yang mana juga dapat disebut ninggali kedato dari hal ini, konsekuensi yang diperoleh laki-Iaki ini yaitu kehilangan hak serta kewajiban maupun tanggung jawab wewenangnya dari keluarganya sendiri, karena telah meninggalkan rumah mereka dan dianggap lepas dari keluarganya. Dengan kata lain hak sebagai ahli waris pun dicabut dan hilang dari tangannya. Namun dalam perkawinan, tak dapat dipungkiri terjadi berbagai kemungkinan adanya permasalahan di kedepannya, seperti dalam hal terjadi perpisahan atau cerai antara suami dengan istri tersebut (Sudarsana LB. Putu, 2005: 12).

\section{METODE PENELITIAN}

Dalam penyusunan penelitian ini menggunakan metode empiris, metode ini dapat digunakan buat mengamati hasil dari tingkah laku manusia berupa peninggalan aset raga ataupun arsip (Fajar \& Achmad, 2015) yang mana perujukannya berdasarkan pada pendekatan sosiologis, pendekatan perundang-undangan, konseptual, kasus dan pendekatan hukum adat. Ada beberapa sumber data yang pertama, data primer adalah data yang diperoleh di tempat penelitian yaitu dengan melakukan wawancara, dokumentasi serta observasi. Data primer/dasar, yaitu data yang diperoleh ke lapangan, berupa pengamatan (observasi), ataupun wawancara (Efendi \& Ibrahim, 2016:149). Yang kedua adalah data sekunder, data ini diperoleh dari penggunaan Awig-Awig Desa Adat Peliatan, UndangUndang Perkawinan No.1 Tahun 1974 serta KUHPerdata atau BW hingga buku-buku literatur, jumaljurnal terkait dengan penelitian ini. 


\section{HASIL DAN PEMBAHASAN}

\section{Kedudukan Suami Dalam Kawin Nyeburin Menurut Awig-Awig Desa Adat Peliatan}

Berdasarkan rujukan Pasal 38 Undang-Undang Perkawinan Nomor 1 Tahun 1974, beberapa sebab dari putusnya suatu perkawinan dapat terjadi dikarenakan keputusan berpisah masing-masing pihak atau perceraian, kematian salah satu atau kedua belah pihak dan adanya putusan dari pengadilan. Dalam hal perkawinan nyeburin ini putus karena kematian salah satu dari mereka, maka istri misalnya pihak yang ditinggalkan akan menjadi janda, dan masih berhak untuk tetap tinggal atau menetap dalam rumah suaminya, sedangkan apabila perkawinan putus karena perceraian maupun putusan dari pengadilan, setiap istri yang bercerai dengan suaminya akan dikembalikan dan pulang ke rumah gadisnya yaitu rumah orang tuanya. lni dalam istilah di Bali disebut Mulih Deha, walau di beberapa daerah sebutannya bisa saja berbeda. Dalam hal perkawinan nyeburin, peran laki-laki (Purusa) seperti tanggung jawab, hak serta kewajibannya dalam keluarga berkebalikan atau di reverse dengan perempuan yang disebut Predana, sehingga kedudukan serta statusnya terbalik, Untuk itu, ketika terjadi putusnya suatu perkawinan maka kedudukan dari laki-laki yang berperan sebagai Predana ini sama seperti yang dimiliki oleh perempuan pada umumnya, berikut konsekuensinya pun sama, namun mengikuti beberapa syarat serta tatacara yang lebih dikhususkan yang diatur dalam aturan hukum adat atau awig-awig setempat.

1) Dalam hal perkawinan nyeburin putus karena meninggalnya istri sebagai purusa maka suami ebagaijanda predana masih dapat menetap di rumah istrinya, atau juga dapat memilih untuk kembali pulang ke rumah orang ruanya.

2) berbeda jika putus karena perceraian, pihak laki-laki sebagai predana tak lagi memiliki hak untuk tetap tinggal dengan dan di rumah mantan istrinya, sehingga diharuskan untuk pulang ke rumah orang tuanya. Sehingga berkemungkinan untuk kembali menjalani hidup sebagai anak orang tuanya dengan rumpun keluarganya, inilah konsekuensi dari perkawinan nyeburin ketika perceraian terjadi, pihak laki-laki dirugikan.

Terkait permasalahan akibat dari perkawinan nyeburin ini baik yang perkawinannya puus karena perceraian ataupun kematian sang istri dalam hukum nasional atau positif kita yaitu KUHPerdata dan juga UU Perkawinan No. 1 Tahun 1974 masih belum ada yang mengaturnya karena memang hal ini masih bersifat adat saja, karena hanya berlaku pada daerah yang mengakui hukum adat itu sebagai aturannya atau awig-awignya. Untuk itu kedudukan serta status dari si laki-laki ini dapat dicari bahasannya selain ini dari pada hukum waris yang berlaku di Bali.

Dalam Desa Adat Peliatan ubud Gianyar contohnya, mengenai substansi atau dasar hukumnya perkawinan nyeburin dapat dilakukan asalkan sesuai dengan ketentuan hukum adat atau awig-awig yang ada di sana dan tetap selaras dengan ketentuan hukum positif yang ada yaitu UU Perkawinan No. 1 tahun 1974. Status sebagai janda atau balu lanang merupakan istilah yang dipakai jika laki-laki bercerai dari hasil perkawinan nyeburin, sehingga statusnya diistilahkan sebagai berikut. Ketika perceraian terjadi, dan si laki-laki pulang ke rumahnya, maka hak serta kewajibannya tak dapat dipulihkan termasuk hak warisnya, sebaliknya, status dan kedudukan sebagai layaknya anak perempuan melekat tanggung jawab itu kepadanya. Waiau di Desa Adat Peliatan Ubud Gianyar, kepulangan dari si laki-Iaki ini pasti akan diterirna dengan tangan terbuka oleh keluarganya, ini disebut Kerob Kundul dalam istilah Bali. (Penetja, 2000)

Hak-hak serta kewajiban dari laki-Iaki yang perkawinan nyeburinnya putus karena meninggal istrinya disamakan seperti status seorang janda pada umumnya, untuk itu jika si laki-laki memilih untuk pulang ke rumah orang tuanya maka ia sudah tak memiliki hak yang sama seperti dahulu sebelum ia menikah, inilah yang disebut dengan Mulih deha di Bali. Perkawinan nyeburin terlaksana biasanya dikarenakan dalam hal ini pihak keluarga wanita tak rnerniliki keturunan laki-laki yang memikul tanggung jawab sebagai Purusa dan ahli waris, sehingga bertindak layaknya laki-laki atau purusa dengan meminang laki-laki dari keluarga yang memiliki anak laki-laki lebih dari pada satu orang. Ada istilah sentana rajeg, jika hanya ada seorang anak perempuan dari keluarga wanita tersebut, sehingga ia diangkat menjadi istilah Sentana Rajeg. (Kaler, 2002). Janda laki-laki/balu lanang selama melaksanakan dharmanya atau kewajiban serta tanggung jawabnya yang benar dalam rumah tangganya, maka hak untuk menikmati atau mendapatkan warisan dari almarhum istrinya akan terjadi. Ini dapat berlangsung selama ia tetap melaksanakannya. Untuk itu kewajiban-kewajiban yang 
dimiliki disamakan seperti seorang janda jika tetap memilih tinggal atau menetap di rumah almarhum istrinya.

\section{Faktor yang MendorongPelaksanaan Perkawinan Nyeburin di Desa Adat Peliatan}

Pengaruh adat serta budaya hingga agama memengaruhi bagaimana perkawinan yang terjadi dalam suatu daerah tersebut. Dalam sistem patrilinial, kedudukan terpenting dan dominan dimiliki anak lakiIaki, sehingga mendapatkan porsi lebih besar dari anak perempuan sebagai saudaranya. Namun hal ini juga berbanding lurus dengan beban serta tanggung jawab yang harus dipikul anak laki-laki untuk mengurus permasalahan adat/istilahnya ngayah banjar, mengurus barang-barang pusaka, memelihara tempat suci, serta kewajiban lain kepada leluhur misalnya. Namun lain hal ketika hanya terdapat anak perempuan dalam keluarga tersebut, maka pemakaian istilah Sentana Rajeg yang menjadikan kedudukan anak perempuan sebagai Predana dapat dilakukan dengan meminang laki-laki dari keluarga yang memiliki lebih dari satu laki-laki inilah yang disebutperkawinan nyeburin atau nyentana (Dharmayuda, 2001). Berdasarkan hal tersebut di atas, menurut Bapak I Ketut Sandi, Bendesa Adat, Desa Adat Peliatan Ubud beliau mengatakan bahwa faktor yang mendorong pelaksanaan perkawinan Nyeburin di Desa Adat Peliatan, antara lain:

1) Faktor yang datang dari pihak wanita ada dua faktor yakni faktor eksternal dan internal.

Faktor eksternalnya terdiri dari:

a) Karena perrnintaan orang tua si wanita akibat tidak mempunyai anak laki-laki dan hanya mempunyai anak perempuan saja

b) Karena adanya rasa cinta dan tresna orang tua terhadap anak perempuannya

c) Karena adanya keinginan dari keluarga si wanita untuk memberikan harta warisan yang sama terhadap anak perempuan.

Faktor internalnya terdiri dari:

a) Karena adanya rasa cinta dan tresna dari wanita kepada laki-laki

b) Besarnya rasa cinta si wanita terhadap kedua orang tuanya

c) Karena si wanita hamil di luar nikah akibat dari si laki-laki tersebut, sehingga si wanita memaksa si laki-laki untuk bersedia menikahinya dengan jalan perkawinan nyentana

2) Faktor yang datang dari pihak laki-laki ada dua faktor yakni faktor eksternal dan internal.

Faktor eksternalnya terdiri dari:

a) Karena perrnintaan orang tua si laki-laki agar hubungan di antara keluarga pihak laki-laki dengan keluarga pihak perempuan sernakin erat

b) Karena didesak oleh si wanita akibat si laki-Iaki telah menghamilinya.

Faktor internalnya terdiri dari:

a) Karena adanya rasa cinta dan tresna dari laki-laki kepada wanita

b) Karena keinginan si laki-Iaki akibat dari tidak betah tinggal di rumah asalnya. (Wawancara dilakukan dengan informan I Ketut Sandi Bendesa Adat Peliatan Ubud, pada hari Senin, 7 Desember 2020).

Sedangkan informasi yang peneliti dapatkan dari responden I Nengah Dharma selaku (Predana) dan Ni Luh Sukerti selaku (Purusa), faktor yang mendorong responden ini melakukan perkawinan nyeburin antara lain:

a) Karena adanya saling mencintai dari kedua belah pihak.

b) Karena permintaan orang tua si wanita yang tidak memiliki keturunan laki-laki. (Wawancara penelitian dilakukan di Banjar Kalah Peliatan pada tanggal 16 Januari 2021 di Desa Adat Peliatan).

Selanjutnya Komang Agustiya selaku (Predana) dan Koming Ayu Sukerti selaku (Purusa), faktor yang mendorong responden ini melakukan perkawinan nyeburin antara lain:

a) Karena adanya saling mencintai di antara kedua belah pihak

b) Karena sudah banyak merniliki saudara laki-laki

c) Karena permintaan orang tua si wanita yang tidak merniliki keturunan laki-laki. (Wawancara peneliti dilakukan di Banjar Tengah Peliatan pada tanggal 17 Januari 2021, di Desa Adat Peliatan). 
Sedangkan yang ketiga atas nama 1 Gede Sukrada selaku (Predana) dan Ni Made Cipta Rahayu selaku (Purusa), faktor yang mendorong informan ini melakukan perkawinan nyeburin antara lain:

a) Karena adanya saling mencintai di antara kedua belah pihak.

b) Karena masih ada hubungan keluarga besar satu sama lain atau dalam satu sanggah besar

c) Karena permintaan orang tua si wanita yang tidak memiliki keturunan laki-laki. (Wawancara peneliti dilakukan di Banjar Tebasaya Peliatan pada tanggal 19 Januari 2021, di Desa Adat Peliatan).

\section{SIMPULAN DAN SARAN}

\section{Simpulan}

Berikut ini peneliti rangkum beberapa faktor yang mempengaruhi terjadinya pelanggaran lain khususnya di daerah Bali:

a) Kedudukan suami selaku Predana dalam kawin Nyeburin menurut Awig-Awig Desa Adat Peliatan, bila putusnya perkawinan baik yang masih tinggal di rumah istrinya ataupun yang telah pulang ke rumah asalnya (mulih deha/truna), belum ada yang mengatur secara tegas baik di dalam KUHPerdata (BW) maupun di dalam Undang-Undang Nomor I Tahun 1974 tentang Perkawinan, maka dengan demikian kedudukan dan status laki-laki Bali yang beragama Hindu yang melaksanakan perkawinan dalam bentuk nyeburin, akan dibahas dalam hukum waris yang berlaku secara umum di Bali.

Faktor yang mendorong pelaksanaan perkawinan Nyeburin di Desa Adat Peliatan:

a) Faktor yang datang dari pihak keluarga wanita (sebagai Purusa). Karena permintaan orang tua si wanita akibat tidak mempunyai anak laki-laki dan hanya mempunyai anak perempuan saja Karena adanya rasa cinta dan tresna orang tua terhadap anak perempuannya Karena adanya keinginan dari keluarga si wanita untuk memberikan harta warisan yang sama terhadap anak perempuannya.

b) Faktor yang datang dari pihak keluarga laki-laki (sebagai Predana) Karena adanya saling mencintai di antara kedua belah pihak Pihak yang laki \{berubah sebagai Predana) memiliki saudara laki-laki lebih dari I (satu) orang Permintaan yang sangat mendasar dari orang tua pihak wanita (sebagai Purusa).

\section{Saran}

Kepada Prajuru Desa Adat Peliatan Ubud, diperlukan Awig-Awig Adat terperinci dan jelas tentang perkawinan dalam bentuk Nyeburin, mengenai kedudukan laki-Iaki yang berstatus sebagai Predana bila kelak perkawinannya putus dan kedudukan di rumah istrinya bila kelak perkawinannya putus karena kematian si istri. Mengingat kedudukannya yang sangat lemah sebaiknya bila laki-laki kawin nyeburin dibekali dengan sedikit harta benda (JiwaDana) dari orang tua agar kelak jika ada hal yang tak diinginkan oleh laki-laki tersebut dia sudah ada persiapan dan tak lagi menyusahkan keluarga di rumah asalnya. Serta untuk menghindari sengketa yang akan timbul di kemudian hari. Untuk itu kedudukan serta status dari si laki-laki ini harus jelas agar hukum waris yang berlaku tidak terlalu merugikan pihak laki-laki.

Kepada Masyarakat Desa Adat Peliatan Ubud, khususnya laki-laki, diperlukan pemahaman perkawinan dalam bentuk Nyentana Nyeburin, mengenai kedudukan laki-laki yang berstatus sebagai Predana bila kelak perkawinannya putus, dan kedudukannya di rumah asalnya bila kelak terjadi Mufih Deha. Jika terdapat Pengecualian atas pelaksanaan Hukum Adat Waris serta mengenai Hak-Hak dan kewajiban laki-Iaki yang mulih deha agar dilaksanakan secara benar dan berdasarkan hukum atau aturan yang ada (Hukum Nasional maupun Hukum Adat) dengan maksud dikemudian hari tidak menimbulkan sengketa.

\section{DAFTAR PUSTAKA}

Anggraini, P. M. R., \& Gunawijaya, I. W. T. (2018). Hukum Adat Kekeluargaan Dan Kewarisan Di Bali. Jurnal Hukum Hindu STAHN Mpu Kuturan Singaraja, Vol. 2(1).

Dharmayuda, I. M. S. (2001). Desa Adat Kesatuan Masyarakat Hukum Adatdi Propinsi Bali. Upada Sastra, Denpasar. 
Efendi, J \& Ibrahim, J. (2016). Metode Penelitian Hukum: Normatif dan Empiris. KencanaFajar, Mukti; Achmad, Y. (2015). Dualisme Penelitian Hukum (Normatif \& Empiris). Pustaka Pelajar, Yogyakarta.

Kaler, I.G. K. (2002). Butir-butir Tercecer Tentang Adi Bali. Bali Agung, Denpasar

Koentjaraningrat, R.M (2000). Masyarakat desa di Indonesia. Lembaga Penerbit Fakultas Ekonomi Universitas IndonesiaLembaga Penerbit Fakultas Ekonomi Universitas Indonesia, Jakarta.

Penetja, I. G. (2000). Aneka Catalan Tentang Hukum Adat Bali (cetakan II). Guna Agung, Jakarta.

Pudja, M. A. (1974). Pengantar Tentang Perkawinan Menurut Hukum Hindu. Dirjen Bimas Hindu \& Budha Depag, Jakarta.

Sudarsana, I. B. P. (2002). Makna Upacara Perkawinan Hindu: Ajaran Agama Hindu. Yayasan Dharma Acarya, Denpasar.

Sutardjana, I. K. G. (2006). Kedudukan Janda terhadap Harta peninggalan Suami Menurut Hukum Waris Adat Bali. Universitas Airlangga., Jakarta. 